\title{
Trends of Augmented Reality Applications and Research throughout the World: Meta-Analysis of Theses, Articles and Papers between 2001-2019 Years
}

\author{
https://doi.org/10.3991/ijet.v14i22.11768
}

\author{
Murat Tezer \\ Near East University, Nicosia, Turkey \\ Ezgi Pelin Y1ldı $\left({ }^{\bowtie}\right)$ \\ Kafkas University, Kars, Turkey \\ yildizezgipelin@gmail.com
}

Alfiya R. Masalimova

Federal University, Kazan, Russia

Albina M. Fatkhutdinova

Financial University under the Government of the Russian Federation,

Moscow, Russia

Marina R. Zheltukhina

Volgograd State Socio-Pedagogical University, Volgograd, Russia

Elmira R. Khairullina

Kazan National Research Technological University, Kazan, Russia,

\begin{abstract}
Our aim in this research was to analyze studies in the area of Augmented Reality applications and research throughout the world using metaanalysis methods in order to determine trends in the area. For the purpose of the study, a total of 1008 pieces of research, published between 2001 and 2019 and selected by purposeful sampling method were analyzed. Trends of Augmented Reality applications and research throughout the world were examined under 13 criteria. These criteria were; index, year of publication, number of authors, country of research, area of research, method, education grade, sample group, sample number, data collection method, bibliography number, analysis techniques, purpose of research, and research trends. These data were interpreted based on percentage and frequency. In Augmented Reality, technologies are integrated in many fields such as education technology, engineering arts, visual arts education and special education.
\end{abstract}

Keywords - Augmented Reality Applications, Augmented Reality in Education, Meta-Analysis, Publication Classification. 


\section{Introduction}

"Augmented Reality Applications" have become increasingly popular in recent years as a result of developing technologies. In 2008, in a Horizon report issued by New Media Consortium (NMC), Augmented Reality (AR) technology was foreseen to play an important role in conjunction with mobile devices after 2010 and wearable technologies after 2013.AR projects are supported within the context of the FATIH (Increasing Opportunities and Improving Technology Movement) project as mentioned in the TUBITAK (Scientific and Technological Research Council of Turkey) Human-Computer Interaction Call. Accordingly, the use of AR technology in the classroom will increase. AR applications will be standardized both in smart phones and tablet PCs. For example, we can what apartments are for sale or for rent using the camera on our mobile devices, and we can read comments about the food of a restaurant we plan to visit using an AR application [1]. A 2D gesture annotation provides a simple way to annotate the physical world in augmented reality for a range of applications such as remote collaboration. Such innovative applications will prove to be convenient with AR.

Augmented Reality has been defined by a number of different researchers. Augmented reality according to [2]. is a live and interactive environment that is formed by adding virtual objects to real images obtained by the camera. AR, according to another definition, is the whole range of technologies that allows the user to see the real world developed, enriched or augmented by adding information such as text, image, voice etc. [3], [4]. Augmented reality, according to [5], is a derivative of virtual reality. Consequently, they are environments in which reality is not reproduced, but rather supported.

When the historical development of AR is examined it can be seen to be a system that was developed to provide information about the flight which appeared on the front windscreen of World War IIaircraft in the form of the Airborne Interception Radar Gun sighting Project. Even though this system reflected the AR technologies as a whole, it was one of the first examples of the development procedures associated with such technology [6]. Paradigmatic changes have occurred in AR technologies with variations in terms of functionality in the form of wide and wearable technologies benefiting from the developed features of applications in connection with the appearance of Information and Communication Technologies. These technologies have started to be used in many different areas [7].

[8] AR is a new technology that is likely to have an impact in education. This claim is supported by the Horizon Reports from 2004 to 2010 which describe AR as a technology that brings the computer world to the human world [9]. AR is different from virtual reality technology because AR combines the real world with computer graphics, while virtual reality immerses the user in a computer-generated world.

It is possible to classify AR types into three categories: geographical positioning, objects positioned over reality, and interactive AR applications. When the most commonly used areas are examined, it is possible to say that military, medical and health, tourism and travel, marketing and sales, public services, games, social interaction, 
industrial uses, education and culture are in the forefront of AR technology use [10]; [11].

If we mention the integration of AR to education in today's world, we consider the point of view that students are growing up in a multimedia world and integrating with the technology as part of the digital native or digital generation; it is possible to say that they may become disinterested with traditional approaches to learning because of the rich content available in the training-education environment, leading to a decrease in interest and motivation with regard to traditional lessons. In this regard it is estimated that AR applications will have a different role to play during the process of achieving desired behaviors in the teaching and learning process, involving the placing of different point of views on the subjects and helping to inculcate positive attitudes to lessons that will lead to an increase in interest and motivation [12], [13], [14], [15].

The relevant research is examined; in their study [16], aimed to examine the reviews released on augmented reality applications in education, merging the results obtained in the studies that are independent from each other, and providing a new viewpoint for the studies that will be conducted in the future. The meta-analysis method has been used in their study. 15 out of 171 reviews, whose effect size of the data may be calculated, and released between the years 2005 and 2015 have been included in the meta analytic effect size analysis. The reviews were intended to examine the efficiency of augmented reality applications in education and were selected after scanning the SCI and SSCI Indices. The names and the abstracts of the reviews were taken as bases in the classifying according to the target audience and subjects. It was determined as a conclusion in the study that the average effect size of the augmented reality applications in education was $\mathrm{ES}=0.677$. It was determined that the applications performed by using the augmented reality technology in education had a positive effect on students, and that this effect was at medium level that could not be underestimated according to Thalheimer and Cook Classification. In their study [17], reviews the research that has been conducted on AR. The review describes the application of AR in a number of fields of learning including Medicine, Chemistry, Mathematics, Physics, Geography, Biology, Astronomy and History. The review of the results of the research shows that, overall, AR technologies have a positive potential and advantages that can be adapted in education. Otherwise in their study [18], reports a systematic review of literature on augmented reality in educational settings considering the factors mentioned before. In total, 32 studies published between 2003 and 2013 in 6 indexed journals were analyzed. A short summary of the main findings of this review are: The number of published studies about AR in education has progressively increased year by year specially during the last 4 years. Science and Humanities \& Arts are the fields of education where AR has been applied the most. Health \& welfare, Educational (teacher training) and Agriculture are the research fields that were the least explored fields [19]. AR has been mostly applied in higher education settings and compulsory levels of education for motivating students [20]. The main purpose of using AR has been for explaining a topic of interest as well as providing additional information. AR educational games and AR for lab experiments are also growing fields. The main advantages for AR are: learning gains, motivation, interac- 
tion and collaboration. Limitations of AR are mainly: difficulties maintaining superimposed information, paying too much attention to virtual information and the consideration of AR as an intrusive technology. AR has been effective for: a better learning performance, learning motivation, student engagement and positive attitudes. reviews of studies that compare student learning in AR versus non-AR applications. The findings on the positive impact are: Increased content understanding, Learning spatial structures, language associations, long-term memory retention, Improved collaboration and motivation. The findings on the negative impact are: attention tunneling, Usability difficulties, ineffective classroom integration, learner differences. Reviews considered papers published in IEEE Xplore. Authors applied a meta-analysis and a qualitative analysis in the dimensions of display metaphors, content creation and evaluation techniques. Authors conclude that there are three main affordances of AR: real world annotation, contextual visualization and vision-haptic visualization. Also, authors state that the three affordances are supported by existing theories like: multimedia learning theory, experiential learning and animate vision theory.

\subsection{Purpose of the research}

The purpose of this research -Research on Augmented Reality and Applications throughout the world is to reveal research trends by classifying relevant publications.

\section{$2 \quad$ Method}

\subsection{Research design}

This research involves a meta-analysis study using content analysis. Meta-analysis is a method that aims to obtain access to common results by using statistical tools with the aim of synthesizing research results by combining the research on a specific issue, and trying to decrease the restrictions of the individual studies (Büyüköztürk et al., 2011).

\subsection{Population sampling}

The population of the research comprises databases, journals, congresses, symposia and conferences through the world in the area of Augmented Reality.

The research sample consists of databases incorporating Augmented Reality applications research between 2001 and 2016; Scopus, IEE XPLORE, IEEE Transactions on Education, Science Direct, EBSCO, Computer \& Graphics, Web of Science, Taylor \& Francis, Proquest, Ulakbim (Turkish National Academic Network and Information Center) and Turkish Council of Higher Education Thesis Search (YÖK). It also includes articles in journals; Journal of Instructional Technologies \& Teacher Education, Journal of European Education, Journal of Educational Technology \& Society, Journal of Information Technology Education, International Journal of Engineering Science Invention (IJESI), Journal of Computational Science, Media Educa- 
tion Research Journal (MERJ), Visualization in Engineering - a Springer Open Journal, International Journal of Technology Enhanced Learning, Journal of Software Engineering and Applications, Journal of Education and Science, Journal of Educational Sciences Gazi University, The Turkish Online Journal of Educational Technology (TOJET), Pegem Journal of Education \& Instruction , Journal of Education Faculty Sakarya University (SUJEF), Journal of Science and Engineering Sciences Afyon Kocatepe University, Journal of Education Faculty Mersin University and papers delivered in congresses, symposia and conferences; 210 pieces of research in total in the International Conference on Technologies for Interactive Digital Storytelling and Entertainment (2003), the International Conference on Computer Graphics (2004), the International Conference on Engineering Education (2008), the EDEN Open Classroom Conference (2011), the Academic Information Congress (2013), the EduRe Virtual Conference (2014), the 9th International Computer \& Instructional Technologies Symposium (ICITS, 2015), and the 17th International Conference on Electronic Commerce (ICEC, 2015).

\subsection{Data collection}

Initially databases, journals, congresses, symposia and conferences relating to AR applications and research between 2001 and 2019 within world were searched, followed by a similar world-wide search. The findings were examined and interpreted. The reason for choosing 2001 as the initial point was that the first publication on Augmented Reality appeared that year.

\subsection{Data analysis}

The data obtained as a result of the search is presented in tabular form. The reason why this approach is followed is because of the fact that both the study constituting imagery and allowing to have idea relating to the researches performed at first sight. The data were interpreted based on percentage and frequency with regard to the research. After general descriptions were identified below the tables, the similarities and differences seen in the research were analyzed in detail using meta-analysis.

\subsection{The validity of the research}

The data have been collected appropriately for meta-analysis purposes, and appropriate analysis methods have been used. The studies have been numbered to make sure that every study is represented once in the sample. The coding form that has been developed is applied in the same way to all meta-analysis studies.

\subsection{The reliability of the research}

Two expert opinions have been used to determine the reliability of the data. Studies were coded into moderator variables that fell into two categories; substantive and 
methodological. There were eight substantive variables; index, year of publication, number of authors, country of research, area of research, purpose of research, education grade, bibliography number, and six methodological variables; method, sample group, sample number, data collection method, analysis techniques. The inter-coding consistency has been found to be sufficiently robust with a value of .81; and revised with a Kappa parameter. The Kappa value was found to be .81 in this study. According to Cohen (1988), this value is almost perfect, as it lies between .81 and 1 .

\section{$3 \quad$ Findings}

In Table 1, the studies in the area of Augmented Reality applications research throughout the world were examined in databases, journals, congresses, symposia and conferences as the result "database" was identified as the most content containing source of publications. These databases are "Scopus" with 29,9\% and 302 publication relating to the subject; "Science Direct" with 27,0 \% and 273 publications; and "Web of Science" with $11,7 \%$ and 118 publications. Since a large proportion of research publications on Augmented Reality applications research appear in the Scopus database, it was noted that this database has hosted 15000 journals and publications in area of Educational Technologies.

Table 1. Distribution of studies in the field of Augmented Reality Applications and Research by publication index

\begin{tabular}{|l|l|c|c|}
\hline \multicolumn{1}{|c|}{ Publication Index } & Classification & f & $\%$ \\
\hline Scopus & Database & 302 & 29,9 \\
\hline Science Direct & Database & 273 & 27,0 \\
\hline Web of Science & Database & 118 & 11,7 \\
\hline IEE Xplore & Database & 92 & 9,1 \\
\hline Ebsco & Database & 75 & 7,4 \\
\hline Taylor\&Francis & Database & 42 & 4,1 \\
\hline Proquest & Database & 16 & 1,5 \\
\hline YÖK Tez Tarama & Database & 11 & 1,0 \\
\hline Computational Science Journal & Journal & 10 & 0,9 \\
\hline Ulakbim & Database & 9 & 0,8 \\
\hline Educational technology (theory and practice) & Database & 5 & 0,4 \\
\hline IEEE Transactions on Education & Journal & 3 & 0,2 \\
\hline Computers \& Graphics & Journal & 2 & 0,1 \\
\hline Computers \& Education & Journal & 2 & 0,1 \\
\hline EduRe Journal & Journal & 2 & 0,1 \\
\hline Journal of Educational Technology \& Society & Journal & 2 & 0,1 \\
\hline Journal of Information Technology Education & Journal & 2 & 0,1 \\
\hline $\begin{array}{l}\text { Journal of Instructional Technologies \& Teacher } \\
\text { Education }\end{array}$ & Journal & 2 & 0,1 \\
\hline Journal of European Education & Journal & 2 & 0,1 \\
\hline Journal of Software Engineering and Applications & Journal & 2 & 0,1 \\
\hline Journal of Education and Training Researches & Journal & 2 & 0,1 \\
\hline Int. J. Technology Enhanced Learning & Journal & 2 & 0,1 \\
\hline
\end{tabular}




\begin{tabular}{|l|l|c|c|}
\hline International Conference on Computer Graphics & Journal & 2 & 0,1 \\
\hline International Conference on Engineering Education & Journal & 2 & 0,1 \\
\hline $\begin{array}{l}\text { International Conference on Technologies for } \\
\text { Interactive Digital Storytelling and Entertainment }\end{array}$ & Journal & 2 & 0,1 \\
\hline $\begin{array}{l}\text { International Journal of Engineering Science } \\
\text { Invention }\end{array}$ & Journal & 2 & 0,1 \\
\hline The International Journal of Virtual Reality & Journal & 2 & 0,1 \\
\hline VieJournal & Journal & 2 & 0,1 \\
\hline Media Education Research Journal & Journal & 2 & 0,1 \\
\hline Architecture Planning Art and Design & Journal & 2 & 0,1 \\
\hline Eğitim ve Bilim Dergisi & Journal & 2 & 0,1 \\
\hline Gazi University Journal of Gazi Educational Science & Journal & 2 & 0,1 \\
\hline Afyon Kocatepe University Journal of Science and Engineering & Journal & 2 & 0,1 \\
\hline Mersin University Journal of Educational Science & Journal & 2 & 0,1 \\
\hline Pegem Journal of Education and Training & Journal & 2 & 0,1 \\
\hline $\begin{array}{l}\text { Sakarya University Journal of Educational Science } \\
\text { SUJEF) }\end{array}$ & Journal & 2 & 0,1 \\
\hline EDEN 2011 Open Classroom Conference & Conference & 1 & 0,1 \\
\hline $\begin{array}{l}\text { ICEC (International Conference on Electronic } \\
\text { Commerce) }\end{array}$ & Conference & 1 & 0,1 \\
\hline $\begin{array}{l}\text { ICITS (Computer \& Instructional Technologies } \\
\text { Symposium) }\end{array}$ & Conference & 1 & 0,1 \\
\hline Academic Information Congress & Congress & 1 & 0,1 \\
\hline Total & & $\mathbf{1 0 0 8}$ & $\mathbf{1 0 0}$ \\
\hline
\end{tabular}

Database, journal, conference and congress sequences were followed in the distribution according to the publication of the works in the field of Augmented Reality Practices and Researches. Then the related publications were examined in terms of content in their respective groups (database, journal, conference and congress). According to this;

- When the data bases are examined; the existence of publications related to the use of augmented reality applications and research in the field of medicine, engineering and education has been observed. Simulations, surgical navigation, robotics applications, mobile applications are these studies.

- When the journals were examined, the existence of publications aimed at the use of augmented reality applications and researches in the field of engineering and education was observed. As well as publications in the dimensions of technology, applications, approaches and limitations on augmented reality. According to the related study in the journals, the use of the augmented reality applications in many different areas. Food chemistry, creative drama, law and policy, ballet training, online shopping, visual arts education are examples of different areas.

- When the conferences and congress were examined, it was determined that the tendency in recent years is to support creativity and permanent learning in schools with augmented reality practices. Many applications developed for pre-school and primary school institutions have been identified for this purpose. These are the concept teaching and material application with the augmented reality. 
Table 2. Distribution of increased reality research and applications by publication year and country

\begin{tabular}{|c|c|c|c|c|c|c|c|c|c|c|c|c|c|c|c|c|c|c|c|c|c|}
\hline \multirow[b]{2}{*}{ Countries } & \multirow[b]{2}{*}{ 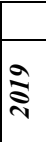 } & \multirow[b]{2}{*}{$\underset{\sim}{\approx}$} & \multirow[b]{2}{*}{$\stackrel{1}{i}$} & \multicolumn{16}{|c|}{ Publication Year } & \multirow[b]{2}{*}{$\begin{array}{c}\text { To- } \\
\text { tal }\end{array}$} & \multirow[b]{2}{*}{$\%$} \\
\hline & & & & $\stackrel{b}{\sim}$ & $\stackrel{\sim}{\approx}$ & $\stackrel{\nabla}{\vec{v}}$ & $\underset{\sim}{\stackrel{2}{*}}$ & $\underset{\sim}{\stackrel{2}{*}}$ & $\underset{\sim}{\sim}$ & $\overrightarrow{\vec{\sigma}}$ & ฐิ & $\stackrel{\infty}{\stackrel{乛}{\sim}}$ & $\hat{\mathfrak{\vartheta}}$ & 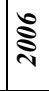 & $\stackrel{n}{2}$ & $\underset{\sim}{\stackrel{2}{2}}$ & $\stackrel{\overbrace{}}{\widetilde{\vartheta}}$ & $\widetilde{\widetilde{\Sigma}}$ & $\overrightarrow{\widetilde{\Omega}}$ & & \\
\hline United States & 62 & 44 & 27 & 19 & 6 & 1 & 2 & & 1 & & 1 & & & & & & & & & 163 & 16,3 \\
\hline \begin{tabular}{|l|} 
Taiwan \\
\end{tabular} & 43 & 33 & 29 & 9 & 3 & 2 & 3 & & & & & & & & & & & & & 122 & 12.2 \\
\hline Germany & 38 & 26 & 30 & 3 & 2 & 2 & 1 & 1 & & & & & & & & & & & & 103 & 10,3 \\
\hline Turkey & 34 & 26 & 12 & 10 & 4 & 3 & 1 & 1 & 2 & 1 & 1 & & & & & & & & & 95 & 9,5 \\
\hline Spain & 31 & 30 & 7 & 7 & 3 & 2 & 5 & 3 & & 1 & & & & & & & & & & 89 & 8,9 \\
\hline Malaysia & 24 & 23 & 15 & 4 & 3 & 2 & & & & & & & & & & & & & & 76 & 7,6 \\
\hline Canada & 27 & 25 & 16 & 4 & $\mathrm{x} 2$ & 1 & 1 & & & & & & & & & & & & & 71 & 7,1 \\
\hline Brazil & 13 & 14 & 10 & 3 & 2 & 1 & & & & 1 & & & & & & & & & & 44 & 4,4 \\
\hline China & 11 & 13 & 9 & 1 & & & & & & 3 & & 2 & & & & & & & 1 & 40 & 4,0 \\
\hline Japan & 16 & 7 & 6 & & 1 & & 2 & & 3 & & & & & & & & & & & 34 & 2,4 \\
\hline Australia & 9 & 5 & 4 & 2 & 1 & & & 1 & & 1 & & & & & & & & & & 23 & 2,4 \\
\hline Britain & 6 & 9 & 3 & 1 & & 1 & & 1 & & & 1 & & 1 & & & & & & & 23 & 2,4 \\
\hline Korea & 7 & 5 & 4 & & 1 & & 1 & & & & 1 & & & 1 & & & 1 & & & 21 & 2,4 \\
\hline Singapore & 6 & 5 & 2 & 1 & & 2 & & & 1 & & & & & & & & & & & 17 & 1,7 \\
\hline Mexico & 4 & 3 & 2 & 1 & & 1 & & & & 1 & & & & & & & & & & 12 & 1,2 \\
\hline Italy & 4 & 2 & 1 & & & & 2 & & & 2 & & & & & & & & & & 11 & 1,1 \\
\hline Norway & 2 & 2 & 2 & & & 2 & & 1 & & & & & & & & & & & & 9 & 0,9 \\
\hline Thailand & 2 & 1 & 1 & 1 & 1 & & & & & & & & & & & & & & & 6 & 0,6 \\
\hline Switzerland & 1 & 1 & & & & & & & & 1 & & & & & & 1 & & & & 4 & 0,4 \\
\hline Czech & 2 & & & & 2 & & & & & & & & & & & & & & & 4 & 0,4 \\
\hline France & 1 & & 1 & & & & & & 1 & & & & & & & & & 1 & & 4 & 0,4 \\
\hline Lithuania & & & & & & & & & & & 1 & & & & & 1 & & & & 2 & 0,2 \\
\hline Egypt & & & & & & & & & & & 1 & & 1 & & & & & & & 2 & 0,2 \\
\hline Portugal & & & & & & 1 & & 1 & & & & & & & & & & & & 2 & 0,2 \\
\hline Russia & & & & 1 & & & & & & 1 & & & & & & & & & & 2 & 0,2 \\
\hline Venezuela & & & & & & & 1 & & & & & 1 & & & & & & & & 2 & 0,2 \\
\hline New Z. & & & & & 1 & & & 1 & & & & & & & & & & & & 2 & 0,2 \\
\hline Greece & & & & & 1 & & & & 1 & & & & & & & & & & & 2 & 0,2 \\
\hline Slovenia & & & & & 1 & & & & & 1 & & & & & & & & & & 2 & 0,2 \\
\hline Slovakia & & & & & & & 1 & & 1 & & & & & & & & & & & 2 & 0,2 \\
\hline Serbia & & & & & & & & & & & & & & & 1 & & & & & 1 & 0,1 \\
\hline Poland & & & & & & 1 & & & & & & & & & & & & & & 1 & 0,1 \\
\hline Sweden & & & & & & & 1 & & & & & & & & & & & & & 1 & 0,1 \\
\hline Hong Kong & & & & & 1 & & & & & & & & & & & & & & & 1 & 0,1 \\
\hline India & & & & & & & & & 1 & & & & & & & & & & & 1 & 0,1 \\
\hline Holland & & & & & & & & & & & & & & & 1 & & & & & 1 & 0,1 \\
\hline Indonesia & & & & & & & & & & & & & & & & & 1 & & & 1 & 0,1 \\
\hline Denmark & & & & & & & & & & & & & & & & & 1 & & & 1 & 0,1 \\
\hline Bulgaria & & & & & & & 1 & & & & & & & & & & & & & 1 & 0,1 \\
\hline Austria & & & & & & & & & & 1 & & & & & & & & & & 1 & 0,1 \\
\hline \multirow[t]{2}{*}{ Total } & 343 & 274 & 181 & 67 & 34 & 21 & 21 & 10 & 11 & 14 & 8 & 3 & 2 & 1 & 2 & 2 & 3 & 1 & 1 & 999 & 100 \\
\hline & & & & & & & & & & & & & & & & & & 0,1 & 0,1 & 100 & \\
\hline
\end{tabular}


It is clear from this that researchers from United States had the most publications on the aforementioned topic with 163 publications (16,3\%). Taiwan follows the United States with 122 publications (12, 2\%). In this context the study done by the countries in the field of the augmented reality applications has been crossed according to years. Countries with a lot of research on augmented reality applications (United States, Taiwan, Germany, Turkey, Spain and Malaysia) may say that these surveys are usually done between 2011 and 2019. So, the work done in the last five years is frequent. According to the publication year of studies into AR applications research in the world and in Turkey, the year 2019 came first with 34 publications of the total. 2018 follows with 26 publications (Table 2). The results obtained here is that there has been an increase in the number of publications in terms of AR applications research. The main reason why issue is being considered is the integration of AR applications with regard to education. When these publications are examined, it can be seen that the main source of such research is Japan, and the subject is "Enrichment of Text Based Books with Virtual Animations by Using Augmented Reality". Since the country to which the 9 articles belonged could not be reached, 999 articles were evaluated.

Table 3. Distribution of studies in the field of Augmented Reality Applications and Research by author numbers

\begin{tabular}{|l|c|c|}
\hline \multicolumn{1}{|c|}{ Author Numbers } & F & \% \\
\hline 2 authors & 261 & 25,8 \\
\hline 3 authors & 178 & 17,6 \\
\hline 1 author & 162 & 16,5 \\
\hline 4 authors & 146 & 14,4 \\
\hline 5 authors & 139 & 13,7 \\
\hline 6 or more authors & 122 & 12,0 \\
\hline Total & $\mathbf{1 0 0 8}$ & $\mathbf{1 0 0}$ \\
\hline
\end{tabular}

In terms of author numbers (Table 3 ) it can be seen that 261 publications had " 2 authors" making up a proportion of $25,8 \%$. Another remarkable point is that single author studies are 16,5\%. In addition, the existence of 122 publications with 6 and more authors is remarkable.

Table 4. Distribution of studies in the field of Augmented Reality Applications and Research by research area

\begin{tabular}{|l|c|c|}
\hline \multicolumn{1}{|c|}{ Research Area } & f & \% \\
\hline Education Technologies & 214 & 21,2 \\
\hline Engineering & 169 & 16,7 \\
\hline Science & 145 & 14,3 \\
\hline Mobile Apps & 132 & 13,5 \\
\hline Robotic Applications & 93 & 9,1 \\
\hline Anatomy & 51 & 4,9 \\
\hline Surgical Navigation & 37 & 3,5 \\
\hline Special Education & 36 & 3,4 \\
\hline Mathematical Sciences & 32 & 3,0 \\
\hline
\end{tabular}




\begin{tabular}{|c|c|c|}
\hline Tourism & 15 & 1,5 \\
\hline Foreign Language Education & 15 & 1,5 \\
\hline Distance Education & 12 & 1,5 \\
\hline Military Aviation Education & 4 & 0,4 \\
\hline Environmental Education & 2 & 0,2 \\
\hline Natural Sciences & 2 & 0,2 \\
\hline Military Marine Education & 2 & 0,2 \\
\hline Food Chemistry & 2 & 0,2 \\
\hline \begin{tabular}{|l|} 
Construction \\
\end{tabular} & 2 & 0,2 \\
\hline Museum Applications & 2 & 0,2 \\
\hline Instructional Design & 2 & 0,2 \\
\hline Architecture & 2 & 0,2 \\
\hline Pedagogy & 2 & 0,2 \\
\hline Psychology & 2 & 0,2 \\
\hline Rehabilitation & 2 & 0,2 \\
\hline Social Media & 2 & 0,2 \\
\hline Creative Drama & 2 & 0,2 \\
\hline Dentistry & 2 & 0,2 \\
\hline Library Management Systems & 2 & 0,2 \\
\hline History & 2 & 0,2 \\
\hline \begin{tabular}{|l|} 
Visual Arts Education \\
\end{tabular} & 1 & 0,1 \\
\hline Visual Tracking Systems & 1 & 0,1 \\
\hline Hospital Applications & 1 & 0,1 \\
\hline Law and Policy & 1 & 0,1 \\
\hline Human Sciences & 1 & 0,1 \\
\hline Military Logistic Support & 1 & 0,1 \\
\hline Media and Communication & 1 & 0,1 \\
\hline Nuclear Engineering & 1 & 0,1 \\
\hline Pre-School Education & 1 & 0,1 \\
\hline Picture-Work & 1 & 0,1 \\
\hline Marketing & 1 & 0,1 \\
\hline Civil Defense & 1 & 0,1 \\
\hline Driving Course & 1 & 0,1 \\
\hline Underwater Life Education & 1 & 0,1 \\
\hline Theater & 1 & 0,1 \\
\hline Aged Care & 1 & 0,1 \\
\hline Early Childhood Education & 1 & 0,1 \\
\hline Ballet Training & 1 & 0,1 \\
\hline Scientific Literacy & 1 & 0,1 \\
\hline Online Shopping & 1 & 0,1 \\
\hline Ethical and evolving technologies & 1 & 0,1 \\
\hline Total & 1008 & 100 \\
\hline
\end{tabular}

According to the research areas of the studies in Augmented Reality Applications Research that were examined, Augmented Reality Technologies were spread out across various areas such as Educational Technologies, Engineering Science, Mobile Applications, and Visual Arts Education. Educational Technologies is the leading research area with 214 publications and $21,2 \%$ of the total (Table 4). Especially in 
recent years, a decrease in the cost of development and improvement with regard to Information and Communication Technologies has provided integration of these technologies in the field of education. In this regard it was decided that integration of augmented reality applications and research as a part of developing and improving technology and development, works. "Engineering", "Science", "Mobile Applications" and "Medicine" followed education in terms of the increase in development and the improvement of AR technologies and provides support of the integration of AR with "Engineering". As undertaking scientific experiments can be expensive, dangerous and difficult in the laboratory, the need for simulation systems has become necessary. It is thought that the increase in publications in the area of Educational Technologies may be explained by the following reasons; in the context of Mobile Applications, smart phones are becoming part of our lives in that they contain several applications that makes human life simpler and which provide support for AR integration. Finally, the integration of AR into medicine is substantial. The increased popularity of integrated surgical operations is thought to be the reason of this. The integration of AR applications in different areas such as "Underwater Life Education", "Theater", "Elderly Care", "Ballet Training", "Scientific Literacy" and "Online Shopping" have also been encountered.

Augmented reality applications begin with the detection of weather, range, flight distances through screens mounted on cockpit of warplane aircraft. When the table is examined it is seen that there are applications where the military area is used for augmented reality. Military aviation education, military marine education, military logistic support, civil defense these applications.

Augmented reality applications are frequently used in the medical field. Surgical navigation practices are the best example. Examples of use of the augmented reality in the field of medicine are included in the relevant table. Anatomy, surgical navigation, rehabilitation, dentistry these applications.

Table 5. Distribution of studies in the field of Augmented Reality Applications and Research by method

\begin{tabular}{|l|c|c|}
\hline \multicolumn{1}{|c|}{ Method } & f & \% \\
\hline Design and development work & 273 & 27,0 \\
\hline Experimental Model & 215 & 24,2 \\
\hline Literary Review & 109 & 10,6 \\
\hline Qualitative Research Methods & 77 & 7,4 \\
\hline Data Collection & 70 & 6,7 \\
\hline Quantitative Research Methods & 66 & 6,2 \\
\hline Mixed Model & 58 & 5,5 \\
\hline Meta-analysis & 35 & 3,2 \\
\hline Pilot Studies & 32 & 2,9 \\
\hline Scale Development Work & 31 & 2,8 \\
\hline Case Study & 30 & 2,7 \\
\hline Empirical Study & 12 & 0,8 \\
\hline Total & $\mathbf{1 0 0 8}$ & $\mathbf{1 0 0}$ \\
\hline
\end{tabular}


In terms of methods used, "Design and Development Studies" led with 273 publications (34.8\%). The reason for this is the integration of the AR applications research, especially in the "Engineering" area and the introduction of improved AR systems in this regard. "Experimental Model" follows with 16.7\%. Qualitative Research Methods are used more frequently than the Quantitative Research Methods. The existence of mixed models which contain both the qualitative and quantitative research methods have been observed in the studies. "Meta-analysis", "Pilot Work", "Scale Development Work" and "Empirical Work follow the Mixed Model approach.

Table 6. Distribution of studies in the field of Augmented Reality Applications and Research by educational level

\begin{tabular}{|l|c|c|}
\hline \multicolumn{1}{|c|}{ Educational Level } & f & \% \\
\hline University & 320 & 50,7 \\
\hline Primary School & 101 & 16,0 \\
\hline Middle School & 65 & 10,3 \\
\hline High School & 58 & 9,4 \\
\hline Pre-School & 35 & 5,5 \\
\hline Special Education & 23 & 3,6 \\
\hline Primary-Secondary Education & 18 & 2,8 \\
\hline Informal Education & 11 & 1,7 \\
\hline Total & $\mathbf{6 3 1}$ & $\mathbf{1 0 0}$ \\
\hline
\end{tabular}

Education level were clearly identified in 377 out of 631 publications in the research (Table 6). When the education level associated with the studies were examined, "University" led with 320 publications (50,7\%). AR applications developed with regard to integrated surgical operations for medical students, efficient use of AR technologies in the classroom by candidate teachers, scenario-based learning etc. all featured. "Primary School" followed university with 101 publications $(16,0 \%)$ including the use of tablet PC technologies in education with AR technologies for primary school students, environmental education and field trips with AR technologies, language skills development based on AR technologies, and educational multimedia content. Primary school is followed by Secondary School studies including Creative Lesson Education with AR, digital content production with AR, application of AR technologies in the natural sciences, etc. Also, the other remarkable point in the table was that "Informal Education" led to a substantial number of publications. An evaluation of informal science education with AR, ballet training with AR integrated expression and integration, use of AR applications on animal phobia etc. are included in the research studies linked to informal education. Primary school is followed by "High school", "Pre-school", "Special Education", and "both Primary and Secondary school" publications. Design development with a fast prototype based on AR technologies for deaf students, AR-supported video based story book design work in order to assess the facial clues of children on the Autism spectrum; magical toys developed with AR technologies for early childhood education in special education, colorful book design with Disney characters by using $\mathrm{AR}$ and 3D modelling etc. are remarkable examples of research relating to Preschool Education. 
Table 7. Distribution of studies in the field of Augmented Reality Applications and Research by sample groups

\begin{tabular}{|c|c|c|}
\hline Sample Groups & f & $\%$ \\
\hline University Students & 181 & 31,8 \\
\hline Primary School Students & 128 & 22,5 \\
\hline Secondary School Students & 110 & 19,3 \\
\hline High School Students & 60 & 13,0 \\
\hline Index, database and magazines (content analysis sample groups) & 52 & 9,1 \\
\hline Tourists & 4 & 0,7 \\
\hline Consumers & 4 & 0,7 \\
\hline Classroom Teachers & 3 & 0,5 \\
\hline Patients & 2 & 0,3 \\
\hline Special Education Students & 2 & 0,3 \\
\hline Special Education Teachers & 1 & 0,1 \\
\hline Pre-school teachers, students and parents & 1 & 0,1 \\
\hline Pre-school teachers and students & 1 & 0,1 \\
\hline Pre-school students & 1 & 0,1 \\
\hline Pre-school students and parents & 1 & 0,1 \\
\hline Secondary school teacher and students & 1 & 0,1 \\
\hline Secondary school student and parents & 1 & 0,1 \\
\hline High school teacher and students & 1 & 0,1 \\
\hline Primary school teachers and students & 1 & 0,1 \\
\hline Primary school student and parents & 1 & 0,1 \\
\hline Primary and secondary school teachers and students & 1 & 0,1 \\
\hline Instructors & 1 & 0,1 \\
\hline Dentists & 1 & 0,1 \\
\hline Nurses and technicians & 1 & 0,1 \\
\hline Experts & 1 & 0,1 \\
\hline Driver candidates & 1 & 0,1 \\
\hline Women & 1 & 0,1 \\
\hline Elderly humans & 1 & 0,1 \\
\hline Total & 568 & 100 \\
\hline
\end{tabular}

The sampling groups in 568 of the 1008 publications in total were identified as seen in Table 7. Publications are mostly Design and Development studies. When the ranges in terms of the samples used in the studies in the Augmented Reality Applications Research area were examined, "University Students" were used in 181 publications (31,8\%). "Primary School" students were used in 128 publications $(22,5 \%)$ and follow University students in order of importance. "Secondary School" students and "High School" students are placed in the table. Another remarkable point in the table is the variety of sampling groups. The generality of AR Applications research was revealed by such diverse sampling groups as "Dentists", "Nurse and Technicians", "Drivers" and "Elderly People". It appears that there is a common tendency when Table 7 and Table 8 are crossed. When the distribution of the augmented reality applications according to education levels is examined, it is seen that the results are favorable to the "universities"; the distributions of the augmented reality applications according to sample groups were examined, it was seen that the results were in favor of the "university students". New multimedia technologies are offering opportunities 
for engaging learning experiences in higher education. One such immersive technology, rich with potential for enhancing the classroom, is augmented reality (AR); "the use of augmented reality (AR) in formal education could prove a key component in future learning environments that are rich populated with a blend of hardware and software applications".

Table 8. Distribution of studies in the field of Augmented Reality Applications and Research by sample numbers

\begin{tabular}{|l|c|c|}
\hline \multicolumn{1}{c|}{ Sample Numbers } & f & \% \\
\hline $1-29$ & 157 & 25,8 \\
\hline $30-59$ & 126 & 22,2 \\
\hline $60-89$ & 85 & 19,3 \\
\hline $90-119$ & 63 & 14,0 \\
\hline $160-200$ & 62 & 7,3 \\
\hline 200 and more & 40 & 7,0 \\
\hline $120-159$ & 35 & 4,4 \\
\hline Total & 568 & 100 \\
\hline
\end{tabular}

When the sampling numbers in the AR Applications Research area were examined, it can be seen that the most commonly found numbers ranged between " 1 and 29 ". This issue was related to the intense use of "Experimental Models" when the range was examined according to the methods of the studies in the Augmented Reality Applications Research area.

Table 9. Distribution of studies in the field of Augmented Reality Applications and Research by data collection tools

\begin{tabular}{|c|c|c|}
\hline Data Collection Tools & f & $\%$ \\
\hline Survey & 154 & 27,1 \\
\hline Interview & 123 & 21,6 \\
\hline Pretest-posttest & 81 & 14,7 \\
\hline Survey-Interview & 52 & 9,1 \\
\hline Observation & 48 & 8,4 \\
\hline Achievement test & 34 & 5,9 \\
\hline Document analysis & 31 & 5,4 \\
\hline Focus group interview & 24 & 4,2 \\
\hline Scale & 21 & 3,6 \\
\hline Total & 568 & 100 \\
\hline
\end{tabular}

In terms of data collection tools, it can be seen that the most common approach was revealed to be "Survey", "Interview" and "Pretest and Posttest" follows "Scale" (Table 9). The frequency of the experimental model in especially publications was considered, it increased the use of pretest-posttest data collection tools. The reason for the frequent use of scales in the published research is because it is assumed that it allows the calculation of total variance over the total points of an item. In addition, another remarkable point is that "Observation", "Interview" and "Document analysis" are data collection methods that are associated with Qualitative studies and have all 
been included in the research. "Success Test" and "Focus Group" are the other data collection tools.

Table 10. Distribution of studies in the field of Augmented Reality Applications and Research by data bibliographic numbers

\begin{tabular}{|l|c|c|}
\hline Bibliographic Numbers & f & \% \\
\hline $26-50$ & 351 & 34,8 \\
\hline $1-25$ & 287 & 28,4 \\
\hline $51-75$ & 175 & 17,3 \\
\hline $76-100$ & 143 & 14,1 \\
\hline 100 and more & 52 & 5,1 \\
\hline Total & $\mathbf{1 0 0 8}$ & $\mathbf{1 0 0}$ \\
\hline
\end{tabular}

The range in terms of the number of references in the Augmented Reality Applications Research area was examined. It was revealed that the most common was "2650 " in 351 publications (41\%). Also, the existence of " $1-25$ " references is also remarkable. In addition, "100 and more" references were encountered in 52 publications (Table 10).

Table 11. Distribution of studies in the field of Augmented Reality Applications and Research by analysis technique

\begin{tabular}{|l|c|c|}
\hline \multicolumn{1}{|c|}{ Analysis Technique } & f & \% \\
\hline Average-Standard Deviation & 81 & 14,2 \\
\hline Descriptive Analysis & 77 & 12,0 \\
\hline T-test & 56 & 9,8 \\
\hline Frequencies/Percentages & 45 & 7,9 \\
\hline Content Analysis & 35 & 6,1 \\
\hline Nonparametric Tests & 35 & 6,1 \\
\hline Others (Post hoc tests, Kappa coefficient etc.) & 34 & 5,9 \\
\hline ANOVA & 32 & 5,6 \\
\hline MANOVA & 25 & 4,4 \\
\hline ANCOVA & 24 & 4,4 \\
\hline AFA and DFA & 24 & 4,4 \\
\hline Pearson Correlation & 23 & 4,3 \\
\hline Cronbach alpha & 22 & 4,3 \\
\hline Qualitative Data Analysis & 22 & 4,3 \\
\hline Factor Analysis & 11 & 2,1 \\
\hline MANCOVA & 11 & 2,1 \\
\hline Predictive Analysis & 11 & 2,1 \\
\hline Total & $\mathbf{5 6 8}$ & $\mathbf{1 0 0}$ \\
\hline
\end{tabular}

The analysis techniques involving the use of "Average/Standard Deviation" in the AR applications research area were examined (Table 11). This analytical technique was used in 81 publications (14,2\%). "Descriptive Analysis" followed Average/Standard Deviation. "t-test", "Frequency-percentage-scale" and "Content Analysis" followed descriptive analysis. Literature compilation studies were predicted to increase the use of content analysis frequency. According to the table use case of 
"Nonparametric Tests", the analysis indicated that Mann-Whitney U, Kruskal-Wallis, Wilcoxon and chi squared tests were performed as part of nonparametric testing. Other analysis techniques were used in 34 publications $(5,9 \%)$. Post hoc tests, Kappa coefficient, content validity rate, content validity index, Kolmogorov-Smirnov Test, Kurtosis Test and Cohen's d are among the other analysis techniques used. Other analysis techniques are "ANOVA, "MANOVA" and "ANCOVA". It is considered that scale development and scale adaptation studies increased the use of EFA and CFA in this regard.

Table 12. Distribution of studies in the field of Augmented Reality Applications and Research by purpose of research

\begin{tabular}{|c|c|c|}
\hline Purpose of Research & $\mathbf{f}$ & $\%$ \\
\hline Design, development and evaluation of AR applications in education & 78 & 7,7 \\
\hline Mobile applications with AR technology & 77 & 7,6 \\
\hline Use of 3D objects with AR /3D Modeling & 77 & 7,6 \\
\hline Surgery with AR / use of simulation systems in integrated medicine & 69 & 6,8 \\
\hline AR Applications in higher education & 68 & 6,7 \\
\hline $\begin{array}{l}\text { Science teaching with AR technology (cooperative-interrogation and scenario-based } \\
\text { learning) }\end{array}$ & 60 & 5,9 \\
\hline Games based learning / mobile educational games with augmented reality technologies & 58 & 5,7 \\
\hline New trends in engineering and architecture with AR technologies & 55 & 5,4 \\
\hline Development of simulation systems with AR technologies & 55 & 5,4 \\
\hline Use of AR technologies in tourism / protection of cultural and touristic heritage & 50 & 4,9 \\
\hline Literature search in AR system and applications & 43 & 4,2 \\
\hline Robotic applications with AR / Human computer interaction & 41 & 4,0 \\
\hline Development of navigation systems with AR applications & 39 & 3,8 \\
\hline Use of AR technologies in teaching mathematics and geometry & 38 & 3,7 \\
\hline Use of AR technologies in history teaching & 37 & 3,6 \\
\hline Creating multimedia content with AR & 31 & 3,0 \\
\hline AR technologies-based language teaching & 30 & 2,7 \\
\hline Use of AR technologies in medical applications & 22 & 2,1 \\
\hline Transfer of virtual objects to real situations with AR applications & 21 & 2,0 \\
\hline $\begin{array}{l}\text { Integration of AR technologies into special education (free AR application for deaf and } \\
\text { disabled autistic students) }\end{array}$ & 20 & 1,9 \\
\hline Civil defense/logistical support with AR technologies & 9 & 0,8 \\
\hline Aerospace education with AR technologies & 7 & 0,6 \\
\hline Museum application with AR technologies & 5 & 0,4 \\
\hline Treatment of psychological disorders with AR technologies & 4 & 0,3 \\
\hline Use of AR technologies in dentistry & 3 & 0,2 \\
\hline Anatomy training with AR technologies & 3 & 0,2 \\
\hline Field and case studies in the field of AR systems and applications & 3 & 0,2 \\
\hline Creative drama education with AR technologies & 1 & 0,1 \\
\hline Ballet training with AR technologies & 1 & 0,1 \\
\hline Theater education with AR technologies & 1 & 0,1 \\
\hline Elderly care & 1 & 0,1 \\
\hline Food separation techniques & 1 & 0,1 \\
\hline AR scale development studies & 1 & 0,1 \\
\hline Total & 1008 & 100 \\
\hline
\end{tabular}


According to Table 12, when the range of aims of the studies in the AR applications research area was examined, it was seen that there is a large variety when it comes to structure. It was revealed that 78 publications making up 7,7\% of the total dealt with "Design, development and evaluation of AR applications in Education". "AR technologies with mobile applications" followed. It is clear from Table 5 that there is a wide variety of structures according to research areas of the studies in the area of AR applications research and that AR applications are wide ranging, ranging from Educational Technologies to Engineering Sciences and from Mobile Applications to Visual Arts Education. The results are compared with Table 5; this finding supports the variety of research aims and revealed in the analysis in fields as diverse as science, medical applications, aviation training, civil defense, logistics support, psychological disorder treatment, theatre education and elderly care.

Table 13.

Distribution of studies in the field of Augmented Reality Applications and Research by research trends

\begin{tabular}{|l|c|c|}
\hline \multicolumn{1}{|c|}{ Research Trends } & f & \% \\
\hline Academic achievement & 142 & 34,2 \\
\hline Attitude & 132 & 32,8 \\
\hline Teacher candidates' opinions & 78 & 7,2 \\
\hline Technology acceptance & 62 & 6,3 \\
\hline Motivation & 52 & 5,0 \\
\hline Student experiences & 45 & 4,3 \\
\hline Student behavior & 33 & 3,1 \\
\hline Teacher opinions & 24 & 2,2 \\
\hline Teacher perceptions & 21 & 1,9 \\
\hline Opinions of teaching staff & 13 & 1,1 \\
\hline Parental Opinions & 11 & 0,9 \\
\hline Patient Opinions & 5 & 0,3 \\
\hline Consistency measurement of behavior & 4 & 0,2 \\
\hline Diffusion & 4 & 0,2 \\
\hline Success, attitude & 4 & 0,2 \\
\hline Learning achievements, real world opinions, attitude & 1 & 0,1 \\
\hline Total & $\mathbf{6 3 1}$ & $\mathbf{1 0 0}$ \\
\hline
\end{tabular}

According to Table 13, when the range of research tendencies in the AR applications research area were examined, the emphasis on "academic success" has frequently attracted attention. "Attitude", "Opinions of Candidate Teachers", "Technological Acceptance" and "Motivation" followed academic success. The remaining research tendencies showed some variation; the variety of the research tendencies as revealed in the analysis were "student behaviors", "academician views", "dissemination", "learning success" and "harmony behaviors". 


\section{Conclusion}

The trends in terms of AR applications research throughout the world were examined using 13 criteria: index, year of publication, number of authors, country of research, area of research, method, education grade, sample group, sample number, data collection method, bibliography number, analysis techniques, purpose of research and research trends. The most important result of research is that almost all areas, from Education Technologies to Engineering Science, Mobile Applications to Visual Arts Education, are included. When the literature is examined, this result is supported by many studies. The educational levels of augmented reality applications are examined; there is a variety of structures from pre-school to university. Apart from these educational levels, augmented reality practices are also used in areas such as special education early childhood education. Rapid development and changes in information technologies, increase in usage of mobile devices, decrease in cost are thought to be factors affecting this result. In addition to this, in this study, different from other studies; the "research trends" criterion was mentioned. The purpose of adding this criterion is to indicate the trends in the area and this structure is important for researchers. Researchers who see deficiencies in the area they will be able to make efforts to eliminate these deficiencies.

\section{Recommendations}

The method related to "design and development work" appears in a significant part of the research. At this point the studies involving research and development (R\&D), and those projects that support researchers in terms of providing them with more information about these methods could be provided to reveal the need for an upgrade of the importance of "qualitative" and "mixed" methods for the studies to be executed by trends. Samples could be selected randomly and objectively with particular attention being paid to the form of sample selection. The reliability of the research can be supported by using more samples. The statistical methods that have been used could be varied for the purposes of analyzing the data. For this purpose, the scope of courses in scientific research methods at a graduate level should be enriched.

\section{Statements on Open Data, Ethics and Conflict of Interest}

No empirical data were collected from individuals or groups during the development of this conceptual paper. As a result, data cannot be accessed and there were no ethical issues related to the selection and treatment of subjects associated with this paper. The authors had no conflicts of interest during the development and publication of the study. 


\section{$7 \quad$ Acknowledgement}

- The work is performed according to the Russian Government Program of Competitive Growth of Kazan Federal University.

- The work is performed according to the Program of Development of Federal StateFunded Educational Institution of Higher Education "Financial University under the Government of the Russian Federation" for 2020.

- The work is performed according to the Project Support of the Federal StateFunded Educational Institution of Higher Education "Volgograd State SocioPedagogical University" by RFBR and the Government of Volgograd Region for 2019.

\section{References}

[1] Çakal, M.A. and Eymirli, E.B. (2012). Augmented reality technologies. Northeast Anatolia Development Agency.

[2] Milgram, P., Takemura, H., Utsumi, A. and Kishino, F. (1994). Augmented reality: a class of displays on the reality-virtuality continuum. In Proceedings of Tele manipulator and Telepresence Technologies (SPIE), 282-292. https://doi.org/10.1117/12.197321

[3] Pastırmacıŏ̆lu, B., Çalışkan, S., Özcan, D., Uzunboylu, H. (2018). Determining a Mobile Internet Acceptance Model of Special Education Teacher Candidates. International Journal of Interactive Mobile Technologies iJIM 12(4):32. https://doi.org/10.3991/ijim.v12i4.9198

[4] Gonzato, J.-C., Arcila, T. and Crespin, B. (2008). Virtual objects on real oceans. GRAPHICON'2008, Moscow, Russia 49-54.

[5] Azuma, R., T. (1997). A Survey of augmented reality in presence: Tele operators and virtual environment, 355-385. https://doi.org/10.1162/pres.1997.6.4.355

[6] Vaughan-Nichols, S. J. (2009). Augmented reality. No longer a novelty. Computer, 42(12), 19-22. https://doi.org/10.1109/MC.2009.380

[7] Altinpulluk, H. and Kesim, M. (2015). Paradigm shifts in augmented reality from the past to the present. Anadolu University, Open Education Faculty, Distance Education Department, Eskişehir.

[8] Martin, S., Diaz, G., Sancristobal, E., Gil, R., Castro, M., \& Peire, J. (2011). New technology trends in education: Seven years of forecasts and convergence. Computer \& Education, 57, 1893-1906. https://doi.org/10.1016/j.compedu.2011.04.003

[9] Madden, L. (2011). Professional augmented reality browsers for smartphones: Programming for Junaio, Layar \& Wikitude. Wiley Publishing, Inc.

[10] Cepeda-Galvis, P. A. (2018). Educational and Cultural Environments Enriched Using Augmented Reality Technology. New Trends and Issues Proceedings on Humanities and Social Sciences, 4(8), 52-59. https://doi.org/10.18844/prosoc.v4i8.2976

[11] Pinpathomrat, N. (2017). Cultural Model of Information Technology Usage (CMITU). Global Journal of Information Technology: Emerging Technologies, 7(2), 42-49. https://doi.org/10.18844/gjit.v7i2.2227

[12] Bicen, H., \& Bal, E. (2016). Determination of student opinions in augmented reality. World Journal on Educational Technology: Current Issues, 8(3), 205-209. https://doi.org/10.18844/wjet.v8i3.642 
[13] Cruz, C.D.L.O.D.L., Palomo, J., \& Figueroa-Domecq, C. (2017). Improving learning by motivating students to read the news using ICT. Global Journal of Business, Economics and Management: Current Issues, 7(1), 89-98. https://doi.org/10.18844/gjbem.v7i1.1643

[14] Figueroa, C. (2016). he Use of New Data Analysis Techniques in Tourism: A Bibliometric Analysis in Data Mining, Big Data and Structural Equations Models https://www.researchgate.net/publication/315105006 The_Use_of_New_Data_Analysis T ecniques_in_Tourism_A_Bibliometric_Analysis in_Data_Mining_Big_Data_and_Structur al Equations Models

[15] Soykan, E. (2015). Views of students', teachers' and parents on the tablet computer usage in education. Cypriot Journal of Educational Sciences, 10(3), 228-244. https://doi.org/10. $\underline{18844 / \text { cjes.v1i1.68 }}$

[16] Tekedere, H. and Göker, H. (2016). Examining the effectiveness of augmented reality applications in education: A Meta-Analysis. International Journal of Environmental \& Science Education, VOL. 11, NO. 16, 9469-9481.

[17] Saidin, N., F., Halim, N., D. and Yahaya, N. (2015). A review of research on augmented reality in education: Advantages and applications. International Education Studies; Vol. 8, No. 13; 2015 ISSN 1913-9020 E-ISSN 1913-9039. Published by Canadian Center of Science and Education. https://doi.org/10.5539/ies.v8n13p1

[18] Bacca, J., Baldiris, S., Fabregat, R., Graf, S., \& Kinshuk. (2014). Augmented reality trends in education: A systematic review. Educational of Research and Applications. Educational Technology \& Society, 17 (4), 133-149.

[19] Cinar, D. (2017). The Opinions of Teacher Candidates About The Use of Concept Cartoon in Science and Technology Teaching Courses. Contemporary Educational Researches Journal, 7(2), 50-56. https://doi.org/10.18844/cerj.v7i2.636

[20] Matei, A., Rotaru, F. G., \& Cristache, S. E. (2019). Characterization of structure and trends in the higher education. International Journal of Learning and Teaching, 11(2), 66-76. https://doi.org/10.18844/ijlt.v11i2.515.

\section{Authors}

Murat Tezer is a Doctor of Education, he completed his MA (1996) and Ph.D. (2003) at the Faculty of Arts and Sciences, Applied Mathematics and Computer Sciences Department of Eastern Mediterranean. He works with Near East University as a Faculty of Science and Literature, Mathematics Department, Nicosia, Turkey. He has more than 100 publications. He published and cited in many publications in international journals. He directed more than 30 master/doctoral thesis advisor. In addition, he published book chapters about mathematics education in refereed publishing houses. e worked as head of Secondary Science and Mathematics Education Department between the years 2009-2018, Vice-Dean of the Education Faculty of Near East University between the years 2013-2018. In addition, he is executive board member of the Cyprus Educational Sciences Association. E-mail id: murat.tezer@neu.edu.tr

Ezgi Pelin Yldız is a Doctor of Education, she completed MA (2013) and Ph.D. (2018) at the Faculty of Education, Computer Educational and Information Technology Department of Near East University. More than 30 publications she published and cited in many publications in international journals. She is currently working as an Assistant Professor at Kafkas University, Kazım Karabekir Vocational School of Technical Sciences Department of Computer Programming, KARS Turkey. Her re- 
search interests are mobile learning, instructional design, teacher education and training, authentic learning, learning management system. E-mail id: yildizezgipelin@gmail.com

Alfiya R. Masalimova is a Doctor of Education, Professor, Head of the Department of Pedagogy of Higher Education of the Institute of Psychology and Education at Kazan (Volga region) Federal University (18 Kremlyovskaya Street, 420000, Kazan, Russia). She is also the Head of Publication Activity Department of Strategic Academic Unit of Kazan (Volga region) Federal University. Her research interests are connected with the methodology of scientific articles and thesis, mentoring and tutoring, teacher education and training. She has more than 150 published papers in Russian and International journals. E-mail id: alfkazan@mail.ru

Albina M. Fatkhutdinova is $\mathrm{PhD}$ in Law, Associate Professor of the Department of Legal Regulation of Economic Activity at Financial University under the Government of the Russian Federation (49 Lenin gradsky prospect, 125993, Moscow, Russia). She has more than 100 published scientific works in Russia and other countries dedicated to different problems of law methodology. E-mail id: AMFathudinova@,fa.ru

Marina R. Zheltukhina is a Doctor of Philology, Professor of the Department of English Philology of Volgograd State Socio-Pedagogical University (27 Lenin Avenue, 400066, Volgograd, Russia). She is also the Head of the Research Laboratory "Discourse Linguistics», Director of the Center for Communicative Technologies. Her research interests are socio-, psycho- and pragma linguistics, cognitive linguistics, political, business, advertising discourse and media discourse, theories of influence, manipulation, verbal and nonverbal suggestiveness, theory of the comic (humor, irony, satire, sarcasm), cultural semiotics, cultural anthropology, intercultural communication, educational innovations, judicial linguistic examination, globalization linguistics. E-mail id: zzmr@mail.ru.

EImira R. Khairullina, is a Doctor of Education, Professor, Dean of the Faculty of Design and Software Engineering at Kazan National Research Technological University (68 Karl Marks Street, 420015, Kazan, Russia). Her main scientific and professional interests are connected with professional standards and programs, engineering education. She actively studies the problems of adult education, teacher education and educational environment possibilities. She is a member of the Federal Educational Methodical Association of Russian universities on an integrated group of areas of light industry technology, and also a member of dissertation council for the award of scientific degrees. She has more than 100 published articles in Russian and International journals. E-mail id: elm.khair73@gmail.com

Article submitted 2019-09-25. Resubmitted 2019-10-29. Final acceptance 2019-11-03. Final version published as submitted by the authors. 